\title{
TINJAUAN KASUS KEHAMILAN EKTOPIK DI BLU RSUP PROF. Dr. R. D. KANDOU MANADO PERIODE 1 JANUARI 2010 - 31 DESEMBER 2011
}

\author{
${ }^{1}$ Sri Cynthia D. Logor \\ ${ }^{2}$ Freddy W. Wagey \\ ${ }^{2}$ Maria F.T. Loho
}

\author{
${ }^{1}$ Kandidat Skripsi Fakultas Kedokteran Universitas Sam Ratulangi Manado \\ ${ }^{2}$ Bagian Obstetri Ginekologi Fakultas Kedokteran Universitas Sam Ratulangi Manado \\ E-mailvj_beauty@yahoo.com
}

\begin{abstract}
An ectopic pregnancy is a pregnancy with a fertilized ovum, implant and grow in a normal endometrial cavity in the uteri. When pregnancy is experiencing a process of termination (abortion) is called a rupture dectopic pregnancy (KET). This study aims to determine umtuk review cases of ectopic pregnancy in BLU Dr Prof. Dr. R. D. Kandou period 1 January 2010 - 31 December 2011 in terms of age, parity,history of abortion ,historyofcontraceptive/familyplanningacceptors. This is a descriptive retrospective study. The population in this study were all patients who were treated at the department of Obstetrics Gynecology Prof. BLU. Dr. R. D. Kandou Period January 1, 2010 - December 31, 2011. The data has been processed and then presented in the form of frequency distribution table and further discussed base don't heresultsobtained. Conclusion: The results of this study indicate the amount and presentation of the study variables based on the total number of cases. It is recommended that the mother has since given a case of ectopic pregnancy can be lifethreatening emergency, then at the age of susceptible pregnant women ectopic pregnancy is recommended for early detection.
\end{abstract}

Keywords: ectopic pregnancy

\begin{abstract}
Abstrak: Kehamilan ektopik adalah kehamilan dengan ovum yang dibuahi berimplantasi dan tumbuh tidak di tempat yang normal yakni dalam endometrium kavum uteri. Bila kehamilan tersebut mengalami proses pengakhiran (abortus) maka disebut dengan kehamilan ektopik terganggu (KET). Penelitian ini bertujuan umtuk mengetahui tinjauan kasus kehamilan ektopik di BLU RSUP Prof. Dr. R. D. Kandou Periode 1 Januari 2010 - 31 Desember 2011 ditinjau dari umur, paritas, riwayat abortus, riwayat pemakaian kontrasepsi/akseptor KB. Penelitian ini bersifat deskriptif retrospektif. Populasi dalam penelitian ini adalah seluruh pasien yang dirawat di bagian Obstetri Ginekologi BLU RSUP Prof. Dr. R. D. Kandou Periode 1 Januari 2010 - 31 Desember 2011. Data yang diolah kemudian disajikan dalam bentuk tabel distribusi frekuensi dan selanjutnya di bahas berdasarkan hasil yang diperoleh. Simpulan: Hasil penelitian ini menunjukkan jumlah dan presentasi dari variabel penelitian berdasarkan jumlah keseluruhan kasus yang terjadi. Disarankan bagi para ibu karena mengingat kehamilan ektopik merupakan kasus darurat yang dapat mengancam nyawa, maka pada wanita hamil usia rentan kehamilan ektopik disarankan untuk melakukan deteksi dini.
\end{abstract}

Kata Kunci: kehamilan ektopik

Kehamilan ektopik adalah kehamilan dengan ovum yang dibuahi, berimplantasi dan tumbuh tidak di tempat yang normal yakni dalam endometrium kavum uteri. Bila kehamilan tersebut mengalami proses pengakhiran (abortus) maka disebut dengan ke- 
hamilan ektopik terganggu (KET). ${ }^{1,2}$

Penelitian Cunningham tahun 2001: berdasarkan data dari Badan Kesehatan Dunia (WHO), pada tahun 2003 terdapat satu dari $250(0,04 \%)$ kelahiran di dunia mende-rita kehamilan ektopik, dengan jenis ke-hamilan ektopik adalah kehamilan tuba fallopi, yang sebagian besar $(80 \%)$ dialami oleh wanita pada usia 35 tahun keatas serta dilaporkan bahwa $60 \%$ dialami oleh wanita dengan paritas pertama dan kedua. ${ }^{3}$

Insiden kehamilan ektopik meningkat pada semua wanita terutama pada mereka yang berumur 20 sampai 40 tahun dengan umur rata-rata 30 tahun. Kehamilan ektopik paling sering terjadi di daerah tuba falopi (98\%), meskipun begitu kehamilan ektopik juga dapat terjadi di ovarium (indung telur), rongga abdomen (perut),atau serviks (leher rahim). ${ }^{4,5}$

Gejala yang terjadi pada kehamilan ektopik meliputi rasa nyeri di perut samping kiri atau kanan bawah, perdarahan dari vagina, nausea, nyeri bahu dan pusing. Pemeriksaan penunjang yang dapat dilakukan untuk mendeteksi dini kehamilan ektopik dengan pemeriksaan ultrasonografi dan pemeriksaan $\mathrm{HCG}^{6}$

Kehamilan ektopik terjadi pada 1 dari 100 kehamilan. Kemungkinan terjadinya kehamilan ektopik dengan adanya kerusakan tuba falopi karena penyakit radang panggul (PID) atau karena infeksi lain, seperti usus buntu yang pecah atau bedah perut. $^{7}$

Penggunaan kontrasepsi IUD dan pil progesteron dapat meningkatkan terjadinya kehamilan ektopik. Kontrasepsi IUD bisa menyebabkan peradangan di dalam rahim sedangkan pil yang mengandung hormon progesteron juga meningkatkan kehamilan ektopik karena pil progesteron dapat mengganggu pergerakan sel rambut silia di saluran tuba yang membawa sel telur yang sudah dibuahi untuk berimplantasi ke dalam rahim. ${ }^{8}$

Penyebab kehamilan ektopik dapat diketahui dan dapat juga tidak, atau bahkan belum diketahui. Sebagian besar kehamilan ektopik terjadi pada tuba sehingga setiap gangguan pada tuba yang disebabkan infek- si akan menimbulkan gangguan dalam perjalanan hasil konsepsi menuju rahim. Beberapa faktor penyebab kehamilan ektopik, meliputi faktor uterus, tuba dan ovum. Ada juga faktor-faktor yang dapat digeneralisasi sebagai faktor mekanis dan faktor fungsional. $^{9}$

Terjadinya implantasi di dalam lumen tuba dapat terjadi beberapa kemungkinan:

a. Hasil konsepsi mati dini. Tempatnya tidak mungkin memberikan kesempatan tumbuh kembang hasil, konsepsi mati secara dini, karena kecilnya kemungkinan diresorbsi.

b. Terjadi abortus. Kesempatan berkembang yang sangat kecil menyebabkan hasil konsepsi mati dan lepas dalam lumen. Lepasnya hasil konsepsi menimbulkan perdarahan dalam lumen tuba atau keluar lumen serta membentuk timbunan darah kedalam ruang abdomen. Tuba tampak berwarna biru saat dilakukan operasi

c. Tuba fallopi pecah. Karena tidak dapat berkembang dengan baik maka tuba dapat pecah. Jonjot villi menembus tuba, sehingga terjadi ruptura yang menimbulkan timbunan darah kedalam ruangan abdomen. Rupture tuba menyebabkan hasil konsepsi terlempar keluar dan kemungkinan untuk melakukan implantasi menjadi kehamilan abdominal sekunder. ${ }^{10}$

\section{GEJALA KLINIK}

Manifestasi klinis kehamilan ektopik bervariasi dari bentuk abortus tuba atau terjadi ruptura tuba. Sering juga dijumpai rasa nyeri dan gejala hamil muda. Pada pemeriksaan dalam terdapat pembesaran uterus yang tidak sesuai dengan usia tua kehamilan dan belum dapat diraba kehamilan pada tuba. Karena tuba dalam keadaan lembek. ${ }^{11}$ Trias gejala klinik kehamilan ektopik;

\section{Amenorea}

Lamanya amenorea bervariasi dari beberapa hari sampai beberapa bulan. Dengan 
amenorea dapat dijumpai tanda-tanda hamil muda, yaitu morning sickness, mual-muntah, terjadi perasaan ngidam

\section{Nyeri abdomen}

Nyeri abdomen disebabkan kehamilan tuba yang pecah. Rasa nyeri dapat menjalar keseluruh abdomen tergantung dari perdarahan didalamnya. Bila rangsangan darah dalam abdomen mencapai diafragma, dapat terjadi nyeri di daerah bahu. Bila darahnya membentuk hematokel yaitu timbunan di daerah kavum douglas akan terjadi rasa nyeri di bagian bawah dan saat buang air besar.

\section{Perdarahan}

Terjadinya abortus atau rupture kehamilan tuba terdapat perdarahan kedalam kavum abdomen dalam jumlah yang bervariasi. Darah yang tertimbun dalam kavum abdomen tidak berfungsi sehingga terjadi gangguan dalam sirkulasi umum yang menyebabkan nadi meningkat, tekanan darah menurun sampai jatuh dalam keadaan syok. ${ }^{12}$

Diagnosanya yaitu terdapat trias kehamilan ektopik, Terdapat kenaikan beta HCG $200 \mathrm{mIU} /$ lier, Penderita tampak anemis dan sakit, tensi turun/normal dan meningkat, dapat terjadi syok, daerah ujung dingin, perut kembung, terdapat cairan bebas-darah, nyeri saat perabaan. CD menonjol dan nyeri, serviks nyeri goyang, teraba nyeri pada tuba dengan hamil ektopik dan teraba tumor, kavum douglas menonjol dan nyeri pada hematokel tumor dan uterus sulit dibedakan. ${ }^{13}$

Karena kehamilan ektopik dapat mengancam nyawa, maka deteksi dini dan pengakhiran kehamilan adalah tatalaksana yang disarankan yaitu dengan obat-obatan atau operasi. $^{14}$

\section{METODE PENELITIAN}

Penelitian ini bersifat deskriptif retrospektif. Yang bertujuan untuk mengetahui tinjauan kasus di BLU RSUP Prof. Dr. R. D. Kandou. Waktu penelitian dilakukan pada bulan November 2011 - Januari 2012. Populasi: semua pasien yang dirawat inap di Bagian Obstetri dan Ginekologi di BLU RSUP Prof. dr. R. D. Kandou periode Januari 2010-Desember 2011. Sampel: Semua pasien yang di diagnosis Kehamilan Ektopik dengan akseptor KB di bagian Obstetri dan Ginekologi di BLU RSUP Prof. dr. R. D. Kandou periode Januari 2010-Desember 2011.

Pengolahan data dilakukan secara manual dan menggunakan komputer. Data yang terkumpul akan dihitung dan disusun dalam bentuk distribusi frekuensi dan tulisan.

\section{HASIL}

Berdasarkan hasil penelitian di bagian rekam medis RSUP Prof.Dr.R.D.Kandou tentang kasus kehamilan ektopik periode Januari 2010 hingga Desember 2011 diperoleh data yang disajikan dalam bentuk tabel distribusi sebagai berikut:

Tabel 1. Distribusi penderita kehamilan ektopik menurut kelompok umur.

\begin{tabular}{ccccc}
\hline & \multicolumn{2}{c}{$\mathbf{2 0 1 0}$} & \multicolumn{2}{c}{$\mathbf{2 0 1 1}$} \\
\cline { 2 - 5 } Umur & Jumlah & \% & Jumlah & \% \\
\hline$\leq 20$ & 1 & 6,67 & 3 & 11,54 \\
$21-35$ & 9 & 60,00 & 13 & 50 \\
$36-45$ & 4 & 26,66 & 9 & 34,61 \\
$\geq 46$ & 1 & 6,67 & 1 & 3,85 \\
\hline Total & 15 & 100 & 26 & 100 \\
\hline
\end{tabular}

Tabel 2. Distribusi penderita kehamilan ektopik menurut paritas.

\begin{tabular}{ccccc}
\hline \multirow{2}{*}{ Paritas } & \multicolumn{2}{c}{$\mathbf{2 0 1 0}$} & \multicolumn{2}{c}{$\mathbf{2 0 1 1}$} \\
\cline { 2 - 5 } & Jumlah & \% & Jumlah & \% \\
\hline 0 & 2 & 13,33 & 5 & 19,23 \\
1 & 8 & 53,33 & 6 & 23,07 \\
2 & 3 & 20 & 10 & 38,46 \\
3 & 1 & 6,67 & 2 & 7,70 \\
4 & 0 & 0 & 1 & 3,84 \\
$>4$ & 1 & 6,67 & 2 & 7,70 \\
\hline Total & 15 & 100 & 26 & 100 \\
\hline
\end{tabular}


Tabel 3. Distribusi penderita kehamilan ektopik menurut riwayat abortus.

\begin{tabular}{lllll}
\hline Riwayat & \multicolumn{2}{c}{$\mathbf{2 0 1 0}$} & \multicolumn{2}{c}{ 2011 } \\
\cline { 2 - 5 } Abortus & Jumlah & \% & Jumlah & \% \\
\hline 0 & 10 & 71,43 & 22 & 81,48 \\
1 kali & 4 & 28,57 & 3 & 11,11 \\
2 kali & 0 & 0 & 2 & 7,41 \\
$\geq 3$ kali & 0 & 0 & 0 & 0 \\
\hline Total & 14 & 100 & 27 & 100 \\
\hline
\end{tabular}

Tabel 4. Distribusi penderita kehamilan ektopik menurut jenis kontrasepsi.

\begin{tabular}{ccccc}
\hline Jenis & \multicolumn{2}{c}{2010} & \multicolumn{2}{c}{2011} \\
\cline { 2 - 5 } Kontrasepsi & Jumlah & \% & Jumlah & \% \\
\hline- & 9 & 60,00 & 19 & 73,07 \\
IUD & 0 & 0 & 0 & 0 \\
Suntikan & 1 & 6,67 & 5 & 19,23 \\
Kondom & 5 & 33,33 & 1 & 3,85 \\
Pil & 0 & 0 & 1 & 3,85 \\
\hline Total & 15 & 100 & 26 & 100 \\
\hline
\end{tabular}

\section{BAHASAN}

Dari hasil pengumpulan data yang dilakukan dibagian rekam medis di BLU RSUP Prof. Dr. R. D. Kandou Manado pada periode 1 Januari 2010-31 Desember 2011, ditemukan total sebanyak 85 kasus yang terdiagnosis Kehamilan Ektopik. Dengan rincian, pada periode 1 Januari-31 Desember 2010 sebanyak 24 kasus dan pada periode 1 Januari-31 Desember 2011 sebanyak 61 kasus. Namun, dari 85 kasus tersebut, sampel yang diambil hanya 41 kasus saja karena data yang tersedia di rekam medis hanya sebanyak 41 kasus.

Pada Tabel 1, didapati bahwa kasus Kehamilan Ektopik di RSU Prof. Dr. R. D. Kandou Manado pada periode 1 Januari 2010-31 Desember 2011, paling banyak ditemukan pada golongan umur 21-35 tahun yaitu sebanyak 22 kasus $(53,66 \%)$ dan terdapat dua kasus pada kelompok umur 46 tahun ke atas (4,88\%). Di beberapa negara maju menunjukkan Kehamilan Ektopik lebih sering terjadi pada usia yang lebih tua yaitu 30-34 tahun. Hasil penelitian Suparman di RSUP Manado tahun 2001 Kehamilan Ektopik
Terganggu (KET) banyak terjadi umur 2529 tahun berjumlah 23 jiwa (34,33\%). ${ }^{15}$

Pada Tabel 2, didapatkan penderita kehamilan ektopik di RSU Prof. Dr. R.D. Kandou Manado paling banyak terdapat pada kelompik dengan paritas satu, yaitu sebanyak 14 kasus (34,15\%). Sedangkan angka kejadian kehamilan ektopik paling rendah ditemukan pada kelompok dengan paritas empat yaitu satu kasus $(2,44 \%)$. Dan pada wanita dengan kelompok paritas 0 (nulipara) sebanyak delapan kasus (19,51\%). Penelitian di RSUD Arifin Achmad di Pekan Baru selama periode 1 Januari 2003-31 Desember 2005 melaporkan bahwa kehamilan ektopik terganggu terbanyak terjadi pada penderita paritas satu $(35,34 \%){ }^{16}$

Pada tabel 3, didapatkan penderita kehamilan ektopik di RSU Prof. Dr. R.D. Kandou Manado paling banyak terdapat pada kelompok tanpa riwayat abortus, yaitu sebanyak 32 kasus (78,05\%). Sedangkan angka kejadian kehamilan ektopik dengan riwayat abortus sebanyak $21,95 \%$ dan terbanyak diantaranya adalah kasus dengan riwayat abortus sebanyak satu kali, yaitu 17,07\%.

Pada tabel 4, didapatkan penderita kehamilan ektopik di RSUP Prof. Dr. R. D. Kandou Manado paling banyak terdapat pada kelompok dengan riwayat tidak menggunakan kontrasepsi sebanyak 28 kasus $68,30 \%$, sedangkan riwayat yang menggunakan suntikan enam kasus $(46,15 \%)$ dan kontrasepsi kondom sebanyak enam kasus $(46,15 \%)$. Kelompok paling rendah dengan riwayat menggunakan kontrasepsi pil progesteron sebanyak satu kasus $(7,70 \%)$ dan tidak ditemui pada kelompok yang menggunakan kontrasepsi AKDR dan susuk $(0 \%)$. Data yang didapatkan tidak sesuai dengan kepustakaan yang menyatakan bahwa pengguna kontrasepsi dapat meningkatkan terjadinya kehamilan ektopik, khususnya yang menggunakan progesteron karena dapat mengganggu peristaltik tuba sedangkan pengguna IUD tergantung perilaku seksual. Pada penelitian sebelumnya faktor Kehamilan Ektopik yang menggunakan alat kontrasepsi yaitu berjumlah 
48 jiwa $(71,63 \%)$ dan yang tidak menggunakan alat kontrasepsi berjumlah 19 jiwa $(28,36 \%)$. Dan kasus kehamilan ektopik ini paling banyak terjadi pada pemakaian kontrasespsi hormonal berupa suntikan dan kondom dengan presentasi kasus sebesar $46,15 \%$ ini sesuai dengan penelitian yang dilakukan oleh Suparman (2001) bahwa kehamilan ektopik paling banyak ditemukan pada pengguna kontrasepsi hormonal berupa suntikan sebesar $31,34 \%{ }^{17}$

\section{SIMPULAN DAN SARAN}

Dari penelitian yang dilakukan dibagian Rekan Medik RSUP. Prof. Dr. R. D. Kandou Manado, dapat disimpulkan bahwa selama dua tahun (1 Januari 2010 - 31 Desember 2011) ditemukan kasus kehamilan ektopik sebanyak 41 kasus. Kasus kehamilan ektopik paling banyak ditemukan pada golongan umur 25-34 tahun, dengan kelompok riwayat tanpa menggunakan kontrasepsi paling banyak ditemukan.

Mengingat kehamilan ektopik merupakan kasus darurat dan dapat mengancam nyawa, maka pada wanita hamil usia rentan kehamilan ektopik disarankan untuk melakukan deteksi dini. Memberikan penjelasan pada setiap ibu hamil tentang gejala-gejala yang timbul akibat kehamilan tidak normal. Pelayanan yang lebih menyeluruh untuk menurunkan angka kejadian kehamilan ektopik. Perlu adanya sentralisasi data, agar pengambilan data dapat terfokus, sehingga proses pengambilan data lebih akurat.

\section{DAFTAR PUSTAKA}

1. Prawirhardjo S. Ilmu Kandungan. Jakarta: Yayasan Bina pustaka Sarwono Prawirohardjo, 2007.

2. Archadiat CM. Obstetri dan Ginekologi. Jakarta: Penerbit Buku Kedokteran (EGC), 2003.

3. Cunningham $G$, Leveno $K$, Bloom S, Hauth J, Gilstap L, Wenstrom $K$. Obstetri Williams (Edisi Keduapuluhsatu).
Jakarta: EGC, 2005.

4. Curtis GB. Kehamilan Diatas Usia 30. Jakarta: Arcan, 2000.

5. MacDuggall J. Kehamilan Minggu Demi Minggu. Jakarta: Erlangga, 2003.

6. Kehamilan Ektopik [homepage on the internet]. Nodate [cited 2011 Nov 6]. Available from: URL: http://www.klikdokter.com.

7. Curtis GB. Kehamilan Apa Yang Anda Hadapi Minggu per Minggu. Jakarta: Arcan, 1999; hal.30.

8. Constance S. Buku Saku Kebidanan. Jakarta: EGC, 2003; Hal.89.

9. Rachimhadhi T. Kehamilan Ektopik. Dalam: Ilmu Bedah Kebidanan Jakarta: Yayasan Bina Pustaka Sarwono Prawiroharjo, 2005; Hal.198-10.

10. Wibowo B, Rachimhadhi T. Kehamilan Ektopik. Dalam: Ilmu Kebidanan (Edisi Ketiga). Jakarta: Yayasan Bina Pustaka Sarwono Prawiroharjo, 2002.

11. Manuaba IBG. Penuntun Kepaniteraan Klinik Obstetri \& Ginekologi (Edisi Kedua). Jakarta: EGC, 2004; Hal.595.

12. Manuaba IBG. Kapita Selekta Penatalaksanaan Rutin Obstetri Ginekologi dan KB. Jakarta: EGC, 2001; Hal.595.

13. Benson RC, Pernoll ML. Buku Saku Obsetri dan Ginekologi. By The McGrawHill Companies, Inc. Edisi Kesembilan. Penerbit Buku Kedokteran - EGC. 2009

14. Yulaikh L. Seri Asuhan Kebidanan. Jakarta: EGC, 2009.

15. Schwart SI. Kehamilan Ektopik. Dalam: Spencer FC, Shires GT, Huser WC, editor. Intisari Prinsip-Prinsip Ilmu Bedah (Edisi Keenam). Jakarta: EGC, 2000; Hal.59906.

16. Obstetri dan Ginekologi E-infomu. Kehamilan Ektopik Terganggu [homepage on the Internet]. Nodate [cited 2011 Nov 6]. Available from: URL: http://kuliahbidan.wordpress.com/2008/07 /16/gambaran-kasus-kehamilan-ektopikterganggu-di-rsud-arifin-achmadpekanbaru-provinsi-riau-periode-1januari-2003-31-desember-2005/

17. Suparman E. Karakteristik kehamilan ektopik terganggu di Rumah Sakit Umum Pusat Manado. CDK. 2007;34:255. 